\title{
16. Regional Security and the Major Powers: An Overview
}

\begin{abstract}
James Bunce
La sécurité régionale et les grandes puissances : vue d'ensemble

Depuis les années 1980, la région du Pacifique Sud a connu un niveau de plus en plus élevé d'instabilité. Cet article présente une vue d'ensemble de l'état actuel de la sécurité régionale dans le Pacifique Sud en examinant le rôle des grandes puissances extérieures dans la promotion de la stabilité à la fois au sein des Etats de la région et en promouvant la sécurité régionale de façon plus large (ou l'inverse, selon le cas). Plutôt que de présenter une vue d'ensemble complète de l'état de la stabilité de la région, l'article examine la crise actuelle à Fidji et le rôle de trois grandes puissances extérieures, à savoir la Chine, l'Australie et les Etats-Unis. Si d'autres grandes puissances extérieures jouent un rôle vraiment important en matière de sécurité régionale dans le Pacifique Sud, cet article met un accent particulier sur la Chine en tant qu'acteur relativement récent et sur l'Australie, dont l'approche vis-à-vis de la région a connu un changement important au cours de ces dernières années. On examinera également le rôle des Etats-Unis, qui se réduit, et l'on conclura sur le fait qu'en dépit de très nombreux exemples d'instabilité interne dans plusieurs Etats du Pacifique Sud, l'état actuel de la sécurité régionale permet quelque espoir.
\end{abstract}

\section{Introduction}

The South Pacific region has experienced an increasing level of instability in the years since the 1980s. This paper provides an overview of the current state of regional security in the South Pacific region. It does so by examining the role of the major external powers in fostering stability both within regional states, and in promoting security in a wider regional sense (or not, as the case may be). It does not seek to present a comprehensive overview of the state of regional stability though - that is significantly beyond the scope of this paper. Instead, this paper will examine the current crisis in the key state of Fiji, and the role of three major external powers; China, Australia and the United States. ${ }^{1}$ While

1 Editors' Note: For reasons of brevity Dr Bunce's analysis of regional security in the South Pacific has focused on the roles of three of the major powers active in the Oceanic region - China, Australia and the United 
other major external powers do play an important role in South Pacific regional security, this paper will place particular emphasis on China, as it is a relatively new regional player; and Australia, which has seen its approach to the region undergo significant change in the last several years. The US's diminishing role will also be examined, as the perceived US withdrawal from the South Pacific deserves some attention.

Before conducting this overview, it is necessary to discuss exactly what regional security is, and what has the potential to both diminish it. This paper will draw on both old and new conceptions of what enhances and diminishes regional security. Furthermore, it is assumed that there is no imminent threat to the territorial integrity or sovereignty of any South Pacific state. In the absence of such a threat, regional security in Oceania has two facets: internal instability and the effects of external actors' activities. The following list presents a checklist of factors that diminish regional security in the South Pacific and is drawn from a checklist devised by David Hegarty (1987), with only minor adjustments. Diminished security results from:

- Increases in threats and use of force

- Major power rivalry

- Alterations in the balance of power

- Internal instability leading to increased influence for external non-state actors or potentially hostile state actors

- The discovery or placement of new strategic assets

To a degree, all of them are either possible, or are currently happening. Concerns about superpower rivalry escalating in the region may seem to have gone with the Cold War, but according to some commentators, major power contests may be returning. China's increasing role in the region has led to some quite alarmist conclusions. Internal stability is another increasingly common factor that diminishes regional security, but this is offset somewhat by the recent Australian and New Zealand tendency to take a more proactive role in assisting the region to maintain stability. There are some issues with the reasoning behind this more proactive role, particularly the linking of failed states and terrorism, but nonetheless the result has largely enhanced regional security. The wider

States. It is important to note that both France and New Zealand are also significant players with respect to the South Pacific's international and regional security. While France's legitimacy as a Pacific regional power had been contested for decades, that situation changed considerably in the 1990s following the cessation of French nuclear testing in French Polynesia and the settling of the political process in New Caledonia via the Matignon and Noumea Accords of 1988 and 1998 respectively. France is widely accepted as a regional defence and security player being a founding member of the FRANZ Agreement designed largely to assist in natural disaster emergencies in the South Pacific. It is also involved with the ANZUS members in a cooperative framework arrangement on Pacific security and stability issues known as the 'Quadrilateral Defence Forum'. We thank Hélène Goiran for this additional information. 
balance of power in the Pacific has been shifting in recent years, and there is potential for major conflict inherent in this shift. As US power declines relative to that of China, there is a possibility it could result in increased major power competition for influence. This is also related to strategic assets in the region, as both China (in terms of strategic resources) and the US (in terms of its Pacific Fleet) have important strategic interests in the region. This paper begins with a discussion of the implications for regional security of the coup regime in Fiji, before moving on to discuss how Australia conceives of (and its role in support of) regional security. It then moves on to examine China's growing role in the region, and its implications for regional security. The paper concludes with a brief discussion of the perceived US withdrawal from the region.

\section{Fiji}

Since December 2006 the Republic of Fiji has been under a military government. The details and events that led up to and occurred subsequent to the 6 December coup are dealt with elsewhere in this volume, and need not be discussed here. Suffice to say, the military leader Commodore Frank Bainimarama has exhibited no desire to back down and allow elections. After promising in 2007 to hold elections by March 2009, and when it became clear in early 2009 that no preparations were being made, Bainimarama's reasons for the 'Fijian military intervention' switched from the earlier justifications to fixing Fiji's 'sick electoral process' before any election is held. In January 2009, a leaders' meeting of the Pacific Islands Forum was convened, with Bainimarama sending in his stead interim Attorney-General Aiyaz Sayed-Khaiyum. An ultimatum was issued to Bainimarama's government by the Forum leaders: announce an election to be held before the end of 2009 by 1 May or face suspension from the PIF (Toohey 2009: 11).

In April 2009 a panel of judges found Bainimarama's coup unconstitutional; Bainimarama's response was to sack the judiciary, re-appoint himself prime minister, and abolish the constitution. He further announced that no elections would be held until September 2014 after significant constitutional and electoral reform had been carried out. Since, Fiji has been suspended from both the PIF and the Commonwealth. Currently, the military regime is censoring the local media, and after the arrest and expulsion of the Australian Broadcasting Corporation's Sean Dorney, international reporting of events in Fiji has been minimal. Amnesty International has released a report on human rights in Fiji, which condemns the situation in Fiji, and claims that due to the actions of Bainimarama and President Iloilo, rule of law in Fiji has been effectively undermined (Amnesty International 2009). 
While there has been no significant violence, the situation in Fiji is still very serious. One of the largest states in the region, and traditionally one of the most stable, has been under the control of a military government for nearly three years, and it looks as though it will be for another five years yet. This is Fiji's fourth coup in 20 years, and it can be argued that a 'coup culture' seems to be developing. This is a concern for the whole region, as well as Australia, and this concern has been reflected in Fiji's suspension from multilateral institutions like the PIF. Jenny Hayward-Jones painted a pessimistic picture of the direction the economic situation in Fiji could take, arguing that an economic meltdown in Fiji could cause a 'regional meltdown' (Hayward-Jones 2009: 5). Needless to say, this kind of economic turmoil would have dire consequences for regional security.

The implications of the Fiji military regime for regional security go much further than the economic implications. It is significant that no initiative taken by regional or global organisations has had any real effect on the situation in Fiji. As mentioned, Fiji is currently suspended from the PIF and the Commonwealth, and Bainimarama has recently complained to the United Nations that unnamed 'big powers of the South Pacific' have 'used their extensive diplomatic and financial resources to deny Fiji to participate in new peacekeeping operations', which are a very important source of foreign exchange earnings for Fiji (Nicholson 2009: 6).

Furthermore, if the extensive constitutional and electoral reform in Fiji is carried out under a military government, which it looks like it will, future stability in Fiji will be jeopardised. Any such reforms carried out under a military government will have legitimacy issues in the long term, and it sets a precedent that could potentially be followed by future Fijian military leaders: that is, if you do not like the constitution or the electoral system, stage a coup and fix it. This does not herald well for the future state of regional security, if one of the leading states of the region can fall under military control and remain so for nearly a decade. There is very little, if anything, that Australia and other major powers in the region can do about it either - so far no method has proven even partially successful. Fiji is the least aid dependent country in the South Pacific, so withholding aid would not seem to be an effective tool. In any case, China has provided substantial aid to the regime in Fiji since the coup, so even were the economic situation to get worse; there is an alternative source of funding for Bainimarama which places no political conditions on aid recipients. Military intervention is unthinkable - given that the regime is a military one, it is a reasonable assumption that any military intervention would be opposed, and it is impossible to imagine anything being worse for regional security than a war between two or more states in the region. This is not good for the regional security outlook, as it shows that there is very little that outside interests can do to influence the situation in Fiji, which is the least aid-reliant, and the least reliant on outside powers generally, of the South Pacific states. 


\section{Australia}

In the 2000 Australian Defence White Paper, it states that, after the defence of the Australian continent itself:

[Australia's] second strategic objective is to help foster the stability, integrity and cohesion of our immediate neighbourhood, which we share with Indonesia, New Zealand, Papua New Guinea, East Timor and the island countries of the Southwest Pacific. (Department of Defence 2000: 30-31)

This statement came one year after the Australian-led intervention in East Timor to stop the violence that resulted after a vote in the former Indonesian province which resulted in almost 80 per cent of East Timorese choosing independence over continued association with Indonesia. This intervention was a significant break from the past in terms of Australian policy. Since this, and the Australianled RAMSI intervention of 2003, Australia has taken on a much more proactive role in the South Pacific region, and this role does not look like diminishing. This section of the paper will give a brief outline of Australia's involvement in the region since 2006, as well as discussing the 2009 Defence White Paper, Force 2030.

In 2006 Australia made three deployments to neighbouring countries in support of regional security broadly defined. In April, it sent troops and police to boost the ability of RAMSI to deal with riots and unrest in Honiara. Then in late May, troops and police were sent to East Timor to assist in stopping riots, ethnic fighting, as well as a breakdown of law and order. In November, and along with New Zealand, troops and police were sent to Tonga, after pro-democracy protests turned violent. Along with its commitments to the wars in Iraq and Afghanistan, this was the highest operational tempo experienced by the Australian Defence Force (ADF) since the Vietnam War.

Force 2030 expresses the interest Australia holds in regional security in much the same, although much more focused, terms as the 2000 White Paper:

After ensuring the defence of Australia from direct attack, the second priority task for the ADF is to contribute to security and stability in the South Pacific and East Timor. This involves conducting military operations...providing disaster relief and humanitarian assistance, and on occasion by way of stabilisation interventions...(Department of Defence 2009: 54)

While all Australian Defence White Papers contemplate a degree of engagement, Force 2030 was the first to formalise this as a direct and sophisticated component of the calculation of strategic interests (Beazley interview). Prime Minister Kevin Rudd outlined why this was such an important task for Australia to undertake 
in 2008. He talked about Australia having a long-term commitment to helping resolve conflict in East Timor and Solomon Islands, as there is a real risk of 'fragile states disrupting stability and prosperity' in the region, not to mention the humanitarian implications. To ignore these kinds of problems 'runs the risk of refugee outflows to neighbouring states', and a 'wide range of economic, diplomatic, and security initiatives' should be put into play to achieve regional security (Rudd 2008).

It must be remembered that the only time Australian territory has been directly threatened by a hostile power was during World War Two, when Australia was (arguably) threatened with invasion by Japan, or at least enforced strategic isolation. During that time, Australian and US military forces defeated Japan in several key battles, which (again arguably) saved Australia from this threat. These battles occurred in the Coral Sea, Papua New Guinea and Solomon Islands, and never on Australian soil. This has left a noticeable mark on the minds of those who study and make strategic and defence policy in Australia, and has meant that the South Pacific occupies a special place in Australian considerations of its own security. A central tenet of this is that other potentially hostile powers must be denied a foothold in South Pacific states - strategic denial. Essentially, strategic denial involves Australia seeking to deny other external players an influential role in key states in the South Pacific region (at least as far as they relate to Australian security interests) - namely Papua New Guinea, Solomon Islands, Fiji and Vanuatu, as well as East Timor. This strategic denial reached its peak in the Cold War period, when fears over Soviet fishing fleet activities in the region verged on hysteria, and there was always a potential South Pacific Cuba lurking, just waiting to provide a springboard for nefarious influences in neighbouring states. Since the terrorist attacks on the World Trade Centre and the Pentagon of 2001, non-state actors have come to dominate this list of potential threats.

One of the central theses driving the new Australian interventionism since the 2003 RAMSI intervention has been what is generally called the Petri dish scenario. This was first developed in a paper authored by Australian academic Elsina Wainwright for the Australian Strategic Policy Institute about the crisis in Solomon Islands (Australian Strategic Policy Institute 2003). This was released shortly before Australian policy towards the crisis in Solomon Islands that simmered between 1998 and 2003 changed from one of non-intervention, to a so-called deep intervention, involving troops, police and public servants. The Petri dish scenario holds that, should instability in Australia's neighbours lead to a situation where rule of law breaks down, and national governments are effectively unable to control their territory, the likely result would be a failed state. These potential failed states could then become a Petri dish, where all sorts of nasty things like transnational criminals and terrorist groups could 
live and flourish, and pose threats to neighbouring states. Commentators like Kabutaulaka have linked this with the US-led war on terror, which led discussions of security within the US alliance framework to shift from inter- and intra-state conflicts to the threat posed by non-state organisations (Kabutaulaka 2005). The links between the Petri dish thesis and Australian interventionism are also still characterised by the strategy of denial traditionally employed by Australia in its relationship with South Pacific states.

It is important to note that all the interventions carried out by Australia have been at the request of regional government, approved by the main regional multilateral institution (the PIF), and thus have been entirely consensual. That has not prevented some commentators from seeing some overarching design in Australia's activities in the South Pacific. Journalist John Pilger goes as far as to say that Australia is administering a 'hidden empire' that 'stretches from the Aboriginal slums of Sydney to the South Pacific' (Pilger 2008). While this may have been a more reasonable conclusion in the days of the 'deputy sheriff', where Australia was seen to act (and indeed saw itself) as the deputy of the US, events since 2003 have seen the Australian role shift. This paper argues that, in fact, commentators arguing that Australia is implementing some far-reaching plan are far too generous to Australia, and that events are controlling Australian policy, rather than the policy even attempting to control events.

A very important facet of Australian policy towards regional security and capacity building in particular has been the increasingly large role in the various Australian interventions that has been played by the Australian Federal Police (AFP) through its International Deployment Group (IDG). The development of the IDG since its inception in February 2004 has been a valuable and useful policy tool for Australia in its attempts to enhance regional security. Its rationale is 'to provide a formal capacity for the Commonwealth [federal] Government [of Australia] to deploy police offshore with the objective of contributing to regional and international stability and security through the delivery of law enforcement interventions and capacity building programs' (McFarlane 2007: 99). Currently, elements of the IDG are deployed in Solomon Islands, East Timor, Vanuatu, Tonga and Nauru. In Solomon Islands, the IDG personnel forms part of the Participating Police Force, itself a facet of RAMSI, and the focus of their efforts is improving the capacity of the Solomon Islands Police Force. In Vanuatu and Nauru, again the focus is on capacity building within local police forces (Australian Federal Police website). Interestingly, an AFP presence in Papua New Guinea was expelled by the government in May 2004 due to a legal challenge, but it seems that both Australia and Papua New Guinea are working towards establishing a new strategic agreement whereby the AFP could find itself deployed to Papua New Guinea again to strengthen 'the institutional resilience of the Royal Papua New Guinea Constabulary' (Banham 2009). 
This role, combining peace operations with capacity building within regional police forces, is important, especially given the way that Australia defines its approach to regional security. As was discussed above, Australia's approach to these issues is defined by two concepts - strategic denial and the Petri dish scenario. Thus its approach to regional security tends to focus on developing strong national states, so that these states can implement the rule of law, thus preventing non-state actors who profit from lawless environments, and rely on them to function effectively and project their activities into neighbouring states, a foothold in the region. What we are seeing from Australia is the development of a three-pronged regional security strategy. The first focuses on military deployments to establish a peaceful environment in which local governments can control their territory. The second builds the capacity of local law enforcement agencies to establish and maintain the rule of law. And the third, as witnessed in the RAMSI intervention, focuses on building other institutions of state, in the hope that instability can be avoided to begin with if regional governments are more effective economic and financial managers. Whether or not the strategy is effective remains to be seen.

The regional security guarantor role that Australia plays does still complement US policies in a wider regional sense, but it also brings significant benefits for regional states. In times of crisis, whether resulting from political instability or natural disaster, regional states can call on Australia to deploy its significant military and humanitarian capabilities to assist. Australia also provides substantial aid to the South Pacific region - it is the largest single donor. In 2008-9, total aid to PIF member states was around $\mathrm{A} \$ 1$ billion, and this is set to increase in 2009-10. It also has the largest number of diplomatic missions in the region. Many Australian businesses hold significant investments in South Pacific countries, particularly in resource development and extraction. The security guarantor role does serve Australian interests primarily, but, while some states in the region may complain about Australia's heavy-handed approach, or its desire to drive political and economic reform in key states like Papua New Guinea, there are no other real alternatives to Australia when it comes to this key security role. There is no other power with the military and economic capabilities to play this role, especially when one considers the relative withdrawal of the United States from the region.

\section{China}

In the last several years, the People's Republic of China has been moving towards significantly increasing its role and profile in the South Pacific region. It has shown a genuine interest in the region, in terms of development aid and assistance, commercial engagement, and in the growing ethnic Chinese 
community in the region. This section of the paper will examine these three areas of growing Chinese influence in the region, and their impact on regional security.

To begin this discussion however, it is necessary to look at China's rise in the wider regional and global contexts, so as to put this discussion into perspective. Since undergoing economic reforms in the 1980s, China has experienced massive economic growth, and a commensurate increase in its national wealth. With this increase in wealth, has also come an increase in international influence, as China seeks to take its place as a responsible stakeholder in the international system. This has involved a normalisation of its international relations, which experienced considerable tension in the period from the Communist Party defeating the Nationalists and proclaiming the People's Republic in 1949, to the late-1970s.

Accompanying this increase in Chinese power has been a debate amongst scholars as to whether a rising China constitutes a threat, or an opportunity. In other words, will China work towards using its power to upset or uphold the current international status quo? Which one it will choose depends on whether China decides that is has more to gain from challenging the United States' military supremacy, or from peaceful coexistence. This has its inverse as well - it also depends on whether the United States decides to accommodate China's rise, or to contest it.

Insofar as the threat/opportunity debate applies to the South Pacific region, there seem to be two contending schools of thought that broadly align with the positions outlined above. One side argues that Chinese engagement in the region provides a valuable development and economic opportunity (Zhang 2007), while the other contends that China's engagement is intended to serve the purpose of both sidelining Taiwan and undermining 'ties between Pacific island nations and regional powers such as the United States, Australia and Japan' (Windybank 2005; see also Henderson and Reilly 2003). Let us now assess these claims, so as to arrive at a conclusion about China's role in the region.

China's aid to some states in the region has been increasing over the last several years, an increase which has received much attention from academics and commentators in both Australia and the United States (see Lunn and Vaughan 2007). In 2006, during a visit to Fiji, Chinese Premier Wen Jiabao told Pacific leaders that China was 'ready to provide assistance without any political strings attached' (Dobell 2007). During this visit, as part of the first China-Pacific Islands Countries Economic Development and Cooperation Forum, Premier Wen announced a new aid package worth US\$375 million over three years, mostly in the form of concessional loans. Chinese development assistance is in fact administered by the Ministry of Commerce, and takes two main forms. Firstly 
there are concessional loans, which are usually used for large infrastructure projects, and are offered with significant interest-free periods and low interest rates. This makes up the majority of the development aid administered over the last several years. Apart from this, China offers debt relief, grants, technical assistance and scholarships. The scale of the aid program is difficult to determine, but Fergus Hanson of the Lowy Institute has produced some excellent data. Firstly though it is important to note that China only offers aid to countries with a One China policy, and thus the states in the region that recognise Taiwan diplomatically cannot access Chinese assistance.

In 2005, Hanson estimates that China's aid program to the 14 Pacific Islands Forum members totalled around \$US33 million. He estimated that this increased to \$US78 million in 2006, and \$US293 million in 2007. The figure for 2007 is somewhat inflated by a $\$ 160$ million soft loan to Fiji, which is being disbursed over several years and which led to this spike in the figure (Hanson 2008: 1114). Hanson later revised the estimate for 2007 in light of this, with the revised figure of \$100-150 million. Hanson's figure for 2008 is \$100 million, and this takes into account disbursements of the loan to Fiji (Hanson 2009: 3). This makes China a significant player in terms of development assistance to the region again according to Hanson - one of the top three. So it seems that China is well on track to provide the US\$375 million it announced in 2006, heralding the arrival of a new, and major, player in South Pacific politics. A large portion of the assistance has gone towards building some major infrastructure items, such as the new Parliament House in Vanuatu, and the Fiji National Stadium in Suva.

Much of this development aid has been aimed directly at reversing diplomatic recognition of Taiwan. This competition has been going on since Taiwan lost its seat in the United Nations in 1971, and takes the form of vying with mainland China for diplomatic recognition by other countries. This is considered to be Taiwan's 'international space' by the government in Taipei, and it has been shrinking since 2000, sharpening the contest. One of the main battlegrounds of this contest has been the South Pacific. Six South Pacific states currently recognise Taiwan: Kiribati, Marshall Islands, Nauru, Palau, Solomon Islands and Tuvalu.

Three brief example of how this contest manifests itself can be found in Kiribati, Tuvalu and Solomon Islands. It was alleged during the 2003 elections in Kiribati that China and Taiwan were bankrolling candidates. Indeed, when the partethnic Chinese Anote Tong subsequently won the election, he quickly switched diplomatic recognition to Taiwan, reversing a twenty year One China policy. In nearby Tuvalu, Chinese diplomats claimed that Taiwanese money was behind an August 2003 no-confidence vote in Prime Minister Saufatu Sopoanga, who had apparently flown to Beijing to switch recognition (Skehan 2004). The alleged role of Taiwanese money in the 2006 election in Solomon Islands and the subsequent 
burning of Chinatown in Honiara is another example of the relationship this diplomatic contest has to regional security, but there is good news. Since the election in Taiwan of President Ma Ying-jeou in March 2008 there has been a diplomatic thaw, and a tacit understanding has developed between Taiwan and China that they would not attempt to encourage Pacific Island countries to change their diplomatic recognition (Callick 2009). Indeed, since Ma's election in May 2008, of twenty-eight nations which recognise Taiwan, not a single one has changed recognition, despite several states in Central America apparently intending to do so. In the absence of this diplomatic competition, it seems more likely that China can play a positive role in fostering regional security, as most instances of instability relating to China and Taiwan's respective aid programs eventuated because of the diplomatic rivalry.

Development assistance is not the only area in which China has significantly increased its role in the South Pacific. Its diplomatic influence is increasing, with some commentators saying that it is now accepted routine that the first official overseas visit by a new head of government in the region is made to Beijing, not to Canberra' (Henderson and Reilly 2003: 95). It has been estimated in Australia that China now has the most diplomats in the region as well as substantial economic investments. There are more than 3000 Chinese (both state and private) owned businesses registered, with investments estimated at US\$ 1 billion (yang 2009). Chinese trade with the region has undergone a huge increase - between 2004 and 2005 alone it increased from US\$530 million to $\$ 838$ million - and has been largely focused on securing resources needed to drive China's economic boom (Zhang 2007: 370). By 2006 this had increased to US\$1.2 billion (Yang 2009: 3). Alongside this has been an increase in the number of ethnic Chinese living in the South Pacific, and while there are no reliable figures, Ron Crocombe estimates there are some 80,000 (Dobell 2007: 6-7). It is uncertain, however, just how many have arrived recently, and how many have been in the South Pacific for years, if not generations. This is because there has been a Chinese presence in the South Pacific since at least the 1800s, and Chinese traders may have been visiting the region for much longer still.

China has a strong interest in regional security, along with the other major external actors active in the South Pacific. China's significant economic investments rely in internal stability, as the situation with the Ramu nickel mine in Papua New Guinea shows. In May 2009, fights between Papua New Guinean and Chinese workers at the Chinese-owned Ramu nickel refinery sparked riots and looting across Papua New Guinea, and resulted in the shooting of at least four looters, as well as calls by local activists to 'celebrate 2010 New Year with bonfires of all Asian-owned shops all around the country' (Roberts 2009). If China seeks to continue extracting resources necessary to fuel its economic growth from states in the South Pacific region, events such as this must be avoided wherever possible. 
Politics, Development and Security in Oceania

However there are important differences between the perspective China holds on regional security and that of other actors like Australia. One difference can be found in China's approach to the coup regime in Fiji. China's interests are not really engaged by events such as this in the way that Australia's interests are. While Australia has a strong interest in stable and democratic governments, China's direct interest in internal stability is primarily engaged by events such as the riots in Papua New Guinea in 2009, rather than by the existence of non-democratic governments. Furthermore, given the scale of China's aid and assistance to Fiji since the coup in 2006, it does not seem that China intends to avoid lending assistance to Bainimarama's regime in the way that the Commonwealth, Australia, New Zealand, the PIF, the European Union and most of the other major regional actors have. Still, according to the Chinese Foreign Ministry, 'China has maintained good coordination with the US, the European Union, Australia, New Zealand and other development partners in the region in safeguarding regional stability... We are willing to work jointly with all relevant parties to promote stability, development and prosperity in the region' (Callick and Kerr 2009). Overall, the Chinese role is very similar to its role in other parts of the developing world: providing development aid with no strings attached, and investing heavily in both infrastructure and resource development.

As China takes its rightful place as a legitimate international actor, it is only natural that it should play a greater role in world politics. China's interests in commerce and resources in the South Pacific will lead it to become more involved in regional affairs, as will competition for diplomatic recognition with Taiwan, should the diplomatic truce break. In large measure, the China as a threat in the South Pacific thesis relies on the assessment that the region is strategically valuable to China, which is itself subject to dispute (Yang 2009). Should China continue to avoid challenging the US militarily, and should the US continue to accommodate China's rise, there is no reason to see China as a serious threat in the South Pacific; indeed, from the perspective of many Pacific Island countries, China's engagement in the region presents a significant opportunity - what is at question now is how to capitalise on the opportunities presented.

\section{United States}

The US has a special relationship with the Freely Associated States (FAS) namely the Federated States of Micronesia, Marshall Islands and Palau - which are essentially politically independent, but allow the US to provide for their defence amongst other things. The FAS, together with Guam and the Northern Mariana Islands 'have been regarded as a security border' by the US, and their defence is considered vital to maintaining open sea lanes of communication (SLOCs) (Lunn and Vaughan 2007: 5). Much like Australia, the US remembers 
well the Second World War, when its SLOCs with Australia were threatened by Japan, and Australia - vital to the US war effort in the Pacific - was nearly isolated from the US. Furthermore, the US presence in Oceania helped it to bolster its security posture during the Cold War.

The US has been winding down its role in the South Pacific steadily since the end of the Cold War. It has been closed embassies in Solomon Islands and Samoa, aid posts in Papua New Guinea and Fiji, and has wound back its provision of educational assistance in the form of scholarships. At the military level though, the US is looking to expand its presence. Secretary of Defence Robert Gates said in May 2009 that the US was 'actually increasing our military presence [in the central and western Pacific], with new air, naval and marine assets based... in Guam' ('Gates Delivers Keynote Address to Open Asia Security Conference' 2009). Indeed, over the next several years the US intends to spend A $\$ 18$ billion on turning the island of Guam into what the generals are calling an 'unsinkable aircraft carrier' ('Guam: Tip of the Spear' 2007). This, however, is directed squarely at China, and is intended as a warning about China's activities in the Taiwan Strait, rather than being directed towards South Pacific regional security. That task is left to Australia - to quote Gates again, 'Australia remains a steadfast ally... we welcome Australia's new Defence White Paper reaffirming its role regionally and globally, and continue to seek ways to advance common interests together'('Gates Delivers Keynote Address to Open Asia Security Conference' 2009; author's emphasis).

\section{Conclusion}

Despite considerable instances of internal instability in several South Pacific states, the current state of regional security offers some hope. More effective mechanisms to deal with these instances are being developed and implemented by regional powers like Australia and New Zealand, alongside programs to help in preventing their occurrence in the first place. The increased Australian role has both positive and negative elements, but overall Australian interests in regional security align well with the interests of states in the region. While there has been considerable angst displayed over China's increasing role, and the relative withdrawal of the US from the region, it does not seem at this stage that it is a simple matter of China displacing or replacing the US as a major power in Oceania. Rather, it looks more likely that China is simply taking its place as a responsible stakeholder in the region, and that it is happy to work with countries in the region in pursuit of prosperity and development. Concerns about the development of a new Cold War in the region, with China and the US vying for influence has not developed, and looks unlikely to develop at this point, but this in turn depends on how China's rise in a global sense is 
Politics, Development and Security in Oceania

managed by both the US, and China itself. Furthermore, China's engagement offers considerable opportunities in terms of development assistance and aid, without the sometimes onerous strings attached by donors like Australia, and international economic institutions.

\section{References}

Amnesty International. 2009. Fiji: Paradise Lost: A Tale of Ongoing Human Rights Violations: April - July 2009. Amnesty International Publications. Available at https:/www.amnesty.org/en/library/asset/ASA18/002/2009/ en/0024be13-bdd1-47d2-875a-863fff4lf978/asa180022009en.pdf

Australian Federal Police website, http://www.afp.gov.au/international/IDG. html accessed 20 October 2009

Australian Strategic Policy Institute. 2003. Our Failing Neighbour: Australia and the Future of Solomon Islands. Canberra: ASPI Publications.

Banham, C. 2009. 'Federal Police Work on Plan for PNG Return'. The Age (18 September).

Beazley, K. Interview with author.

Callick, R. 2009. 'China, Taiwan end war over aid'. The Australian (10 August): 10.

Callick, R., and Kerr, C. 2009. 'Beijing Given Frank Bainimarama Cold Comfort'. The Australian (2 May).

Department of Defence. 2000. Defence 2000: Our future defence force. Canberra: Department of Defence.

Department of Defence. 2009. Defending Australia in the Asia Pacific Century: Force 2030. Canberra: Department of Defence.

Dobell, G. 2007. 'China and Taiwan in the South Pacific: Diplomatic Chess versus Political Rugby'. Policy Brief. Sydney: Lowy Institute for International Policy.

'Gates Delivers Keynote Address to Open Asia Security Conference'. 2009. American Forces Press Service (30 May).

'Guam: Tip of the Spear'. 2007. Foreign Correspondent, ABC Television (4 September). 
Hanson, F. 2008. 'The Dragon Looks South'. Analysis. Sydney: Lowy Institute for International Policy.

Hanson, F. 2009. 'China: Stumbling Through the Pacific'. Policy Brief. Sydney: Lowy Institute for International Policy.

Hayward-Jones, J. 2009. 'Fiji: the Flailing State'. Policy Brief. Sydney: Lowy Institute for International Policy.

Hegarty, D. 1987.Small State Security in the South Pacific. Working Paper 126. Strategic and Defence Studies Centre, Australian National University, Canberra.

Henderson, J., and Reilly, B. 2003. 'Dragon in Paradise: China's Rising Star in Oceania'. The National Interest. 7(2): 94-104.

Kabutaulaka, T. 2005. 'Australian Foreign Policy and the RAMSI Intervention in Solomon Islands'. The Contemporary Pacific. 17(2): 283-308.

Lunn, T., and Vaughan, B. 2007. The Southwest Pacific: US Interests and China's Growing Influence. Congressional Research Service.

McFarlane, J. 2007. 'The Thin Blue Line: The Strategic Role of the Australian Federal Police'. Security Challenges. 3(3): 91-108.

Nicholson, B. 2009. 'Fiji Troops Excluded from UN Peacekeeping role'. Sydney Morning Herald (28 September).

Pilger, J. 2008. 'Australia's Hidden Empire'. The New Stateman (6 March).

Roberts, G. 2009. 'PNG Vow to Burn all Asian Shops'. The Australian (29 May): 8.

Rudd, K. 2008. The First National Security Statement to the Australian Parliament (4 December).

Skehan, C. 2004. 'Pawns in a Diplomatic Poker Game'. Sydney Morning Herald (18 December): 31.

Toohey, P. 2009. 'Pariah of the Pacific', The Australian (29 January).

Windybank, S. 2005. 'The China Syndrome'. Policy. 21(2): 28-33.

Yang, J. 2009. 'China in the South Pacific: A Strategic Threat?' New Zealand International Review. 34(1): 8-12.

Zhang, Y. 2007. 'China and the Emerging Regional Order in the South Pacific'. Australian Journal of International Affairs. 61(3): 367-381. 